J. Reprod. Fert. (1969) 20, 175-178

\title{
CHEMICAL COMPOSITION OF CATTLE AND BUFFALO SPERMATOZOA AND SEMINAL PLASMA UNDER DIFFERENT CLIMATIC CONDITIONS
}

\author{
BHUPAL SINGH,* B. B. MAHAPATRO AND D. P. SADHU $\uparrow$ \\ Indian Veterinary Research Institute, Izatnagar, U.P., India
}

(Received 25th April 1969)

The present study was undertaken in view of the scanty information available concerning the chemistry of buffalo semen, the low survival of buffalo spermatozoa in storage compared with other cattle (Roy, Pandey \& Rawat, 1960; Singh, 1967) and a report of a greater influence of adverse climatic conditions on the quality of buffalo semen compared with other cattle (Sinha, Gupta \& Roy, 1966). Semen was collected from four Murrah buffalo and four Hariana bulls and the study was made during the seasons mentioned in Table 1. Immediately after collection, semen was stored in a thermos flask containing ice. The spermatozoa and seminal plasma were separated by centrifuging a known volume of pooled semen at low temperature for half an hour. The chemical constituents were determined according to the standard methods described by Hawk, Oser \& Summerson (1954).

The sodium content of the seminal plasma of the two species did not differ significantly, but seasonal differences were noted, indicating higher concentrations in cold, and slightly lower values in hot and hot-humid climates. The potassium and chloride contents of the seminal plasma and the potassium content of the buffalo spermatozoa were higher $(P<0.01)$ than those of the bulls in all seasons.

Steinbach \& Dunham (1961) demonstrated that the motility of the spermatozoa of Arbacia punctulata depended upon the ion gradient (sodium and potassium) in the sperm cells. Cragle \& Salisbury (1959) showed that potassium levels in diluting media, comparable to those found in seminal plasma, had an inhibitory effect on the oxygen consumption, fructose utilization and lactic acid accumulation of bull spermatozoa. These reports indicate that the higher potassium concentrations found in the seminal plasma as well as the spermatozoa of buffalo might, to some extent, be associated with the lower survival of these spermatozoa under storage conditions.

The inorganic phosphorus and calcium contents of the seminal plasma of the two species did not differ significantly, nor did they differ significantly from season to season in the same species.

The total nitrogen content of the seminal plasma of the Hariana bulls was appreciably higher $(P<0 \cdot 01)$ than that of the buffaloes in all seasons. In both the species, the total nitrogen and non-protein nitrogen contents increased

* Present address: Assistant Director, Animal Husbandry Department, Lucknow, Uttar Pradesh, India. $\dagger$ Present address: Professor of Physiology, Bengal Veterinary College, Calcutta, West Bengal, India. 


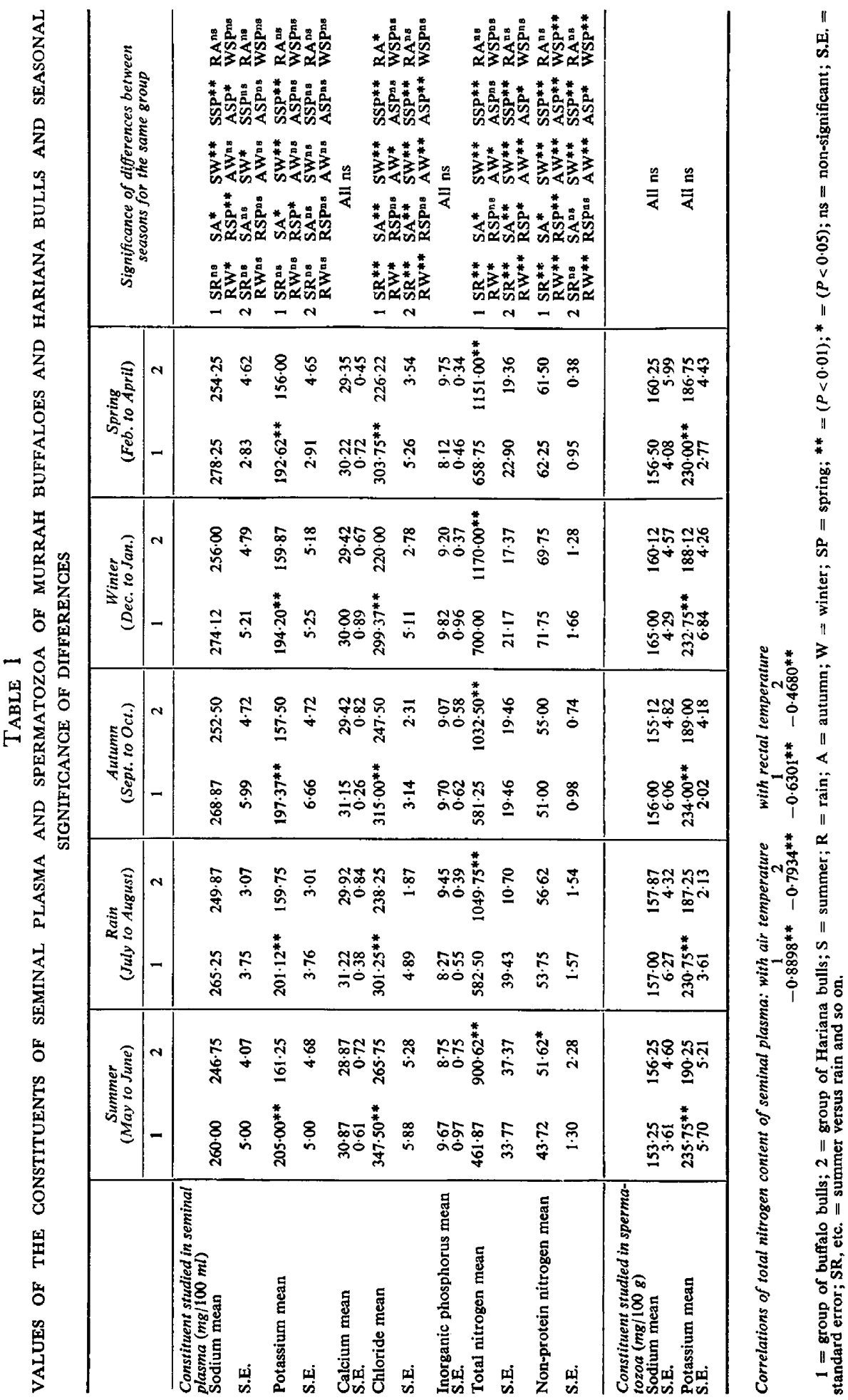


during winter and spring and decreased during summer, and the total nitrogen content showed an inverse relationship with the environmental and rectal temperatures. It has been shown that testosterone has a stimulating effect on protein synthesis (Butler \& Schade, 1958; Wilson, 1962), and a similar influence on the secretion of citric acid and fructose in the seminal plasma (Lindner \& Mann, 1960). Although information about the seasonal level of testosterone in the bull is lacking, the well-known seasonal variations in seminal fructose and sexual activity may be indicative of similar trends in the testosterone secretion. The present work suggests that protein synthesis in the reproductive organs may be influenced by the variable secretion of testosterone under different climatic conditions.

The increased protein content of seminal plasma during winter and spring in both species and the higher protein content of bull seminal plasma compared with that of buffalo might promote the survival of the spermatozoa, at least in those cases where semen is diluted after some time. Tyler \& Atkinson (1950) reported an increase in the viability of sea-urchin spermatozoa after the addition of certain peptides and amino acids, while Rozin (1961) claimed to have achieved fertility by suspending infertile human spermatozoa in cell-free seminal plasma from fertile individuals. The claim of Rozin (1961) seems neither to have been disputed nor established by further work, but VanDemark, Koyama \& Lodge (1965) produced evidence to show that some of the constituents of seminal plasma might be important in the preservation of semen. The evidence revealed in this investigation indicates that the differences in the chemical composition of the semen of the two species, may be of significance in relation to the differences in the viability of their spermatozoa.

The authors thank the Director, Indian Veterinary Research Institute, Izatnagar for providing facilities. The first author (Bhupal Singh) also thanks the Indian Council of Agricultural Research, New Delhi, for awarding a Senior Research Fellowship to carry out this work.

\section{REFERENCES}

Butler, W. W. S. \& SGhade, A. L. (1958) The effects of castration and androgen replacement on the nucleic acid composition, metabolism and enzymatic capacities of the rat ventral prostrate. Endocrinology, 63, 271.

Gragle, R. G. \& Salisbury, G. W. (1959) Factors influencing metabolic activity of bull spermatozoa. IV. $\mathrm{pH}$, Osmotic pressure, and the cations, sodium, potassium, and calcium. F. Dairy Sci. 42, 1304.

Hawk, P. B., Oser, B. L. \& Summerson, W. H. (1954) Practical physiological chemistry, 13th edn. Blakiston, New York.

LiNDNER, H. R. \& MANN, T. (1960) Relationship between the content of androgen steroids in the testes and the secretory activity of the seminal vesicles in the bull. 7. Endocr. 21, 341 .

Roy, A., PandeY, M. D. \& Rawat, J. S. (1960) Composition of bovine semen. Indian F. Dairy Sci. 13, 112.

Rozin, S. (1961) Studies on seminal plasma. Int. F. Fert. 6, 169.

SiNGH, B. (1967) Studies on certain aspects of metabolic activity and livability of buffalo spermatozoa in relation to climate and semen diluents. Ph.D. thesis, Agra University.

Sinha, R. C., Sen Gupta, B. P. \& Roy, A. (1966) Climatic environment and reproductive behaviour of buffaloes. IV. Comparative study of oxygen up-take and aerobic fructolysis by Murrah and Hariana spermatozoa during different seasons. Indian F. Dairy Sci. 19, 18.

Steingach, H. B. \& Dunham, P. B. (1961) Ionic gradients in some invertebrate spermatozoa. Biol. Bull. mar. biol. Lab., Woods Hole, 120, 411. 
Tyler, A. \& Atkinson, E. (1950) Prolongation of the fertilizing capacity of sea-urchin spermatozoa by amino acids. Science, N.Y. 112, 783.

VanDemark, N. L., Koyama, K. \& Lodge, J. R. (1965) Factors affecting immobilization of bovine spermatozoa with $\mathrm{CO}_{2}$ and their subsequent reactivation. F. Dairy Sci. 48, 586.

WiLson, J. D. (1962) Localisation of the biochemical site of action of testosterone on protein synthesis in the seminal vesicle of the rat. 7. clin. Invest. 41, 153. 